\title{
JPEB
}

Jurnal Penelitian Ekonomi dan Bisnis, 4 (1), 2019, Hal: 9 - 22

http://www.jpeb.dinus.ac.id

\section{HARGA SAHAM, NILAI TUKAR MATA UANG DAN TINGKAT SUKU BUNGA ACUAN DALAM MODEL AUTOREGRESSIVE DISTRIBUTED LAG (ARDL)}

\author{
Bara Zaretta $^{1^{*}}$ dan Lenni Yovita ${ }^{2}$ \\ 1,2Program Studi Manajemen, Universitas Dian Nuswantoro Semarang \\ Jalan Nakula I No. 5-11 Semarang, Indonesia \\ *Corresponding Author : bara.zaretta@dsn.dinus.ac.id
}

Diterima: Desember 2018 ; Direvisi: Januari 2019 ; Dipublikasikan: Maret 2019

\begin{abstract}
Previous studies have proven that there is an influence between the exchange rate of Rupiah against the US Dollar and the BI Rate against the JCI. However, using the Autoregressive Distributed Lag (ARDL) model approach in this study more deeply sees the dynamics of long-term and short-term relationships for the variable exchange rate of Rupiah against the US Dollar, the BI Rate and the JCI. The research period began from July 2005 to December 2017, which is the period range of global upheaval which had a considerable impact on Indonesia, specifically the depreciation of Rupiah against the US Dollar. In this study, through the ARDL model the exchange rate, the BI Rate and JCI proved to have long-term cointegration or move together in the long run. Not only long-term, they also have a dynamic short-term relationship that has a fairly high balance speed of adjustment per month.
\end{abstract}

Keywords : The Exchange Rate; BI Rate; JCI; Autoregressive Distributed Lag Model

\section{ABSTRAK}

Penelitian terdahulu banyak yang membuktikan adanya pengaruh antara nilai tukar Rupiah terhadap Dolar Amerika dan BI Rate terhadap IHSG. Dengan menggunakan pendekatan model Autoregressive Distributed Lag (ARDL) dalam penelitian ini lebih dalam lagi melihat dinamika hubungan jangka panjang maupun jangka pendek untuk variabel nilai tukar Rupiah terhadap Dolar Amerika, BI Rate dan IHSG. Periode penelitian dimulai dari Juli 2005 sampai dengan Desember 2017, dimana dalam rentang waktu tersebut banyak terjadi pergolakan global yang memberikan dampak yang cukup besar terhadap Indonesia, salah satunya adalah pelemahan nilai tukar Rupiah terhadap Dolar Amerika. Dalam penelitian ini, melalui model ARDL nilai tukar Rupiah terhadap Dolar Amerika, BI Rate dan IHSG terbukti memiliki kointegrasi jangka panjang atau bergerak bersama - sama dalam jangka panjang. Namun tidak hanya jangka panjang, ketiga variabel tersebut juga mempunyai dinamika hubungan jangka pendek yang mempunyai kecepatan penyesuaian menuju keseimbangan yang cukup tinggi perbulannya.

Kata kunci : Nilai Tukar; BI Rate; IHSG; Autoregressive Distributed Lag Model 


\section{PENDAHULUAN}

Pada saat Indonesia mengalami krisis moneter di tahun 1998 yang silam, pelemahan nilai Rupiah terhadap Dolar AS sempat menyentuh titik terendah melewati kurs Rp. 15.000 per Dolar AS. Krisis moneter 1998 seolah begitu mengesankan bagi masyarakat Indonesia, sehingga setiap terjadi pelemahan terhadap nilai Rupiah akan menimbulkan kekhawatiran tersendiri. Beberapa tahun sesudahnya, tercatat Rupiah sempat melemah cukup serius terhadap Dolar AS. Pada tahun 2005 tepatnya di bulan Agustus Rupiah sempat menyentuh Rp.10.854 per Dolar AS atau terdepresiasi sampai dengan 16\%. Hal tersebut disebabkan karena spekulasi kenaikan tingkat suku bunga Dolar AS dan tingginya inflasi Indonesia yang mencapai 7\%-18\%. Pada tahun 2008 pelemahan tertinggi Rupiah terjadi pada bulan november yang mencapai Rp.12.456 per Dolar AS atau terdepresiasi sampai dengan 32\%. Pelemahan Rupiah di tahun 2008 selain disebabkan tingginya inflasi Indonesia dan kenaikan harga minyak dunia, juga disebabkan krisis yang cukup menghebohkan yaitu mortgage subprime Amerika Serikat. Pelemahan Rupiah terjadi kembali pada tahun 2013, dimana Rupiah menyentuh di angka Rp.12.331 terjadi di bulan desember. Depresiasi Rupiah terhadap Dolar AS tahun 2013 yang mencapai 26,7\% tersebut terutama disebabkan defisit neraca pembayaran, krisis utang Eropa dan wacana pengurangan stimulus di Amerika Serikat. Berlanjut di tahun 2015, pelemahan tertinggi terjadi di bulan september yang mencapai Rp.14.802 per Dolar AS sebagai akibat krisis berkepanjangan di Yunani, penghentian quantitative easing di AS dan kondisi politik karena transisi pemerintahan.

Menghadapi situasi pelemahan Rupiah terhadap Dolar AS, pemerintah Indonesia banyak meluncurkan kebijakan - kebijakan yang diharapkan cukup efektif menghadapi kondisi Rupiah yang terdepresiasi. Diantara sekian banyak paket kebijakan pemerintah, salah satu kebijakan moneter yang digunakan adalah dengan menaikkan tingkat suku bunga atau $B I$ rate. BI rate merupakan suku bunga acuan Bank Indonesia yang merupakan sikap atau kebijakan moneter yang ditetapkan oleh BI dan diumumkan kepada publik. Implementasi dari BI rate pada operasi moneter dilakukan dengan pengelolaan likuiditas di pasar uang. Pengelolaan ini diharapkan akan dicerminkan pada pergerakan suku bunga PUAB (Pasar Uang Antar Bank) overnight yang akan diikuti oleh perkembangan suku bunga deposito dan selanjutnya suku bunga kredit perbankkan. Tingkat suku bunga menjadi hal yang cukup penting dalam pertumbuhan ekonomi suatu negara. Suku bunga menjadi acuan bagi masyarakat dalam menanamkan modalnya. Bilamana suatu tingkat suku bunga naik, maka para pemilik modal akan mengalokasikan dananya pada instrumen investasi yang lain seperti deposito (Novita dan Nachrowi, 2005). Kenaikan suku bunga BI akan mendorong kenaikan selisih antara suku bunga Indonesia dengan suku bunga luar negeri, yang selanjutnya diharapkan investor asing akan menanamkan modalnya di instrumen - instrumen keuangan di Indonesia. Aliran modal ini pada gilirannya akan mendorong apresiasi nilai tukar Rupiah. Pada tahun 2005 Bank Indonesia beberapa kali menaikkan BI-rate yang semula 8,5\% menjadi 12,75\%. Di tahun 2008 BI-rate berangsur naik dari 8\% ke 9,25\%.

Pasar modal mempunyai peranan yang cukup penting dalam perekonomian suatu negara, sehingga pasar modal dapat menjadi indikator ekonomi suatu negara. Pada perekonomian terbuka perkembangan positif dari pasar modal suatu negara akan direspon oleh investor asing dengan pembelian saham di bursa sehingga akan terjadi aliran modal masuk yang pada gilirannya diharapkan akan membuat nilai tukar akan terapresiasi. Demikian juga sebaliknya, bilamana gejolak nilai tukar sangat tinggi sehingga terjadi depresiasi Rupiah, akan sangat berpengaruh buruk terhadap kinerja sektor industri di Indonesia, terutama bagi perusahaavitan yang melakukan impor atau memiliki pinjaman dana dari luar negeri, sehingga pada akhirnya akan mempengaruhi harga saham. 
Beberapa penelitian terdahulu telah menguji hubungan antara harga saham, nilai tukar dan tingkat suku bunga. Mudji Utami dan Mudjilah Rahayu (2003) meneliti tentang peranan profitabilitas, suku bunga, inflasi, nilai tukar dalam mempengaruhi pasar modal Indonesia selama periode terjadinya krisis. Hasil penelitiannya membuktikan bahwa suku bunga dan nilai tukar Rupiah terhadap Dolar Amerika secara parsial mempunyai pengaruh yang signifikan terhadap harga saham selama periode krisis ekonomi di Indonesia. Penelitian senada dilakukan oleh Wiyani dkk (2005) yang melakukan penelitian terhadap saham sektor perbankan yang masuk dalam LQ45, secara parsial tingkat suku bunga dan nilai tukar Rupiah terhadap Dolar Amerika berpengaruh terhadap harga saham. Penelitian dilakukan untuk data harian periode bulan Mei - Juni 2004. Ajaz et al. (2016) dalam penelitiannya di India menemukan bahwa terdapat reaksi asimetri dari harga saham atas perubahan tingkat suku bunga dan nilai tukar. Dalam studi literaturnya Ho dan Iyke (2016) kembali menemukan bahwa tingkat suku bunga dan nilai tukar sangat mempengaruhi perkembangan dari pasar modal.

Pelemahan Rupiah untuk jangka pendek yang selanjutnya direspon pemerintah dengan kebijakan kenaikan suku bunga acuan bank sentral atau BI rate pada beberapa kasus dirasa cukup efektif untuk mendongkrak penguatan nilai tukar. Namun kenaikan suku bunga ini selanjutnya akan memberikan dampak menurunkan harga aset seperti saham dan obligasi. Kondisi krisis keuangan global tersebut yang kemudian mendorong agar lebih memperhatikan saling ketergantungan antara kebijakan moneter dan pasar saham, oleh karena dampak yang cukup merusak dari pergerakan harga aset yang tak terduga terhadap perekonomian. Gavin (1989) dalam Ajaz et al. (2016) menyatakan bahwa memperhatikan hubungan ketergantungan tersebut sangat penting oleh karena pasar saham akan mempengaruhi permintaan agregat, yang pada gilirannya berdampak pada keputusan kebijakan moneter yang menargetkan tingkat suku bunga dan nilai tukar riil. Kembali pada periode tahun 2005 - 2017 yang banyak terjadi pergolakan global yang akhirnya berimbas pada depresiasi Rupiah terhadap Dolar Amerika, apakah kebijakan suku bunga dapat mengatasi pelemahan tersebut dan direspon positif juga oleh pasar modal, yang dalam penelitian ini akan dilihat melalui dinamika hubungan dari ketiga variabel tersebut.

Kerangka kerja teoritis yang berbeda seperti hipotesis efisiensi pasar yang dikembangkan oleh Fama (1965) dan the arbitrage pricing theory (APT) yang dikembangkan oleh Ross (1976) telah digunakan untuk mempelajari dampak perubahan fundamental makroekonomi terhadap return pasar saham. Berdasarkan teori tersebut, para peneliti telah menggunakan berbagai metode ekonometrik untuk mempelajari hubungan antara kebijakan moneter dan respon dari pasar saham. Banyak penelitian menggunakan berbagai macam metode ekonometrika untuk mempelajari dampak kebijakan moneter terhadap harga saham maupun return saham. Beberapa penelitian menggunakan model VAR (Cassola dan Morana, 2004; Ismail dan Isa, 2009) dan menggunakan pendekatan event study (Bernanke and Kuttner, 2005; Chulia et al., 2010; Farka, 2009). Shin et al. (2014) mengembangkan model asymmetric autoregressive distributed lag (ARDL) untuk mendeteksi non-linearitas dan fokus kepada pengaruh jangka panjang dan asimetri jangka pendek antara variabel - variabel ekonomi.

Model Autoregressive Distributed Lag (ARDL) memiliki dua keunggulan yaitu tidak bias dan efisien karena dapat digunakan dengan sampel yang sedikit. Dengan menggunakan ARDL dapat diperoleh estimasi jangka panjang dan estimasi jangka pendek secara serentak, yang akan menghindarkan terjadinya masalah autokorelasi. Selain itu, metode ARDL juga mampu membedakan antara variabel bebas dan variabel terikat. Sebagaimana penelitian yang dilakukan oleh Shin et al. (2014), ARDL mampu mendeteksi non-linearitas dan fokus kepada pengaruh jangka panjang dan asimetri jangka pendek antara veriabel - variabel ekonomi. Oleh karena diasumsikan bahwa kointegrasi linier mempunyai asumsi yang terbatas yang 
bisa membawa pada spesifikasi model yang tidak tepat yang akhirnya akan menghasilkan kesimpulan yang menyesatkan. Namun demikian, belum terlalu banyak penelitian yang mempelajari hubungan antara harga saham, nilai tukar dan tingkat suku bunga yang menggunakan model autoregressive distributed lag (ARDL).

Dengan latar belakang tersebut diatas, dalam penelitian ini kami akan menguji hubungan harga saham, tingkat suku bunga dan nilai tukar, dan menentukan sifat dari hubungan tersebut dengan menggunakan model autoregressive distributed lag (ARDL)

\section{TINJAUAN PUSTAKA}

Perubahan atau perkembangan yang terjadi yang terjadi pada berbagai variabel makroekonomi suatu negara akan mempengaruhi pasar modal. Bilamana indikator ekonomi makro memburuk akan memberikan dampak buruk juga untuk perkembangan pasar modal. Demikian sebaliknya, jika indikator makro ekonomi baik akan memberikan dampak yang baik pula untuk perkembangan pasar modal (Sunariyah, 2006).

\section{Harga Saham dan Tingkat Suku Bunga}

Suku bunga menjadi salah satu acuan masyarakat dalam menanamkan dananya. Pemilik modal akan cenderung menginvestasikan kekayaannya pada suatu aset tertentu yang mampu memberikan tingkat return yang tinggi dengan tingkat risiko tertentu. Bilamana suku bunga cenderung naik maka pemilik modal akan mengalokasikan dananya ke dalam instrumen investasi lain seperti deposito (Novita dan Nachrowi, 2005).

Suku bunga yang tinggi akan berdampak pada alokasi penempatan dana investasi para investor. Investasi pada produk bank seperti deposito mempunyai risiko lebih kecil jika dibandingkan dengan investasi pada saham. Suku bunga yang tinggi akan mendongkrak kenaikan suku bunga simpanan, termasuk deposito, sehingga investor akan cenderung menjual sahamnya dan mengalihkan dananya ke simpanan di bank. Penjualan saham secara serentak akan berdampak pada penurunan harga saham secara signifikan (Arifin, 2007).

Pada banyak kajian tentang kebijakan moneter dan harga saham, dipercaya bahwa kebijakan moneter memberikan dampak yang cukup signifikan terhadap harga aset. Berdasarkan teori klasik, harga sebuah aset sama dengan nilai sekarang dari pendapatan yang diharapkan atas aset tersebut. Bagi perusahaan, harga saham akan menggambarkan discounted present value dari future cash flows. Oleh karena itu, kebijakan moneter sangat berhubungan dengan perubahan tingkat bunga jangka pendek, yang diharapkan akan mempengaruhi harga saham dengan menyesuaikan tingkat diskontonya (Zare dan Azali, 2015).

\section{Harga Saham dan Nilai Tukar Mata Uang}

Hubungan antara harga saham dengan nilai tukar mata uang dapat dilihat melalui penetapan tingkat nilai tukar berdasarkan pendekatan portofolio. Berdasarkan pendekatan ini, naiknya harga saham akan meningkatkan kekayaan investor, yang akan meningkatkan permintaan uang yang selanjutnya akan meningkatkan tingkat suku bunga. Peningkatan tingkat suku bunga akan menarik investasi asing sehingga akan terjadi aliran dana masuk yang selanjutnya akan mengapreasiasi nilai mata uang domestik. Di sisi lain, depresiasi mata uang akan mendorong peningkatan ekspor yang pada akhirnya meningkatkan profitabilitas perusahaan-perusahaan yang melakukan ekspor. Kenaikan profitabilitas perusahaan akan menyebabkan naiknya harga saham. Lebih lanjut, depresiasi mata uang akan meningkatkan biaya memperoleh sumber daya perusahaan yang diperoleh melalui impor, sehingga terjadi peningkatan biaya produksi bagi perusahaan yang tidak berorientasi ekspor. Jika kenaikan biaya tersebut menyebabkan turunnya profit perusahaan, maka akan memberikan dampak penurunan harga saham perusahaan. 
Hasil penelitian yang dilakukan oleh Bahmani-Oskooee dan Sohrabian (1992) menyatakan tidak adanya pengaruh jangka panjang antara harga saham dan nilai tukar pada semua negara yang tergabung dalam G-7. Namun, secara signifikan terdapat pengaruh jangka pendek yang hanya berlangsung selama sehari untuk beberapa negara G-7. Selanjutnya penelitian yang dilakukan oleh Phylaktis dan Ravazzolo (2005) yang menggunakan data bulanan dari periode 1980-1998 untuk Hong Kong, Indonesia, Malaysia, Filipina, Singapura dan Thailand. Mereka menemukan bahwa harga saham dan nilai tukar mempunyai hubungan positif, yang diuji menggunakan metode kointegrasi dan uji kausalitas Granger.

Menggunakan data harian dari tahun 1997-2010 untuk negara India, Indonesia, Jepang, Korea, Malaysia, Filipina, Singapura, Taiwan dan Thailand, Yang et al. (2014) menguji hubungan antara return saham dan nilai tukar. Mereka menggunakan uji kausalitas Granger dan menemukan bahwa selama periode krisis keuangan di Asia, pada semua negara kecuali Thailand, terdapat hubungan antara harga saham dengan nilai tukar.

\section{Model Autoregressive Distributed Lag (ARDL)}

Metode estimasi yang akan digunakan dalam penelitian ini adalah menggunakan pendekatan Autoregressive Distributed Lag (ARDL). Model ARDL dipilih karena ARDL mampu melihat pengaruh $\mathrm{Y}$ dan $\mathrm{X}$ dari waktu ke waktu, berikut juga pengaruh variabel $\mathrm{Y}$ masa lampau terhadap Y masa kini. Model ARDL adalah penggabungan dari antara model Autoregressive (AR) dengan Distributed Lag (DL). Menurut Gujarati dan Porter (2013) model AR merupakan model yang menggunakan satu atau lebih data masa lampau dari variabel dependen diantara variabel penjelas. Adapun model DL adalah model regresi yang melibatkan data pada waktu sekarang dan masa lampau (lagged) dari variabel penjelas.

ARDL tidak memerlukan penelitian dalam hal derajat integrasi dari masing-masing variabel, sehingga dapat menghilangkan ketidakpastian. Pendekatan ini diterapkann dengan mengabaikan variabel-variabel tersebut terintegrasi pada derajat nol, I(0) atau satu I(1) (Pesaran et al, 2001). Keunggulan model ARDL adalah tidak bias dan efisien karena dapat digunakan dengan sampel yang sedikit. Dengan menggunakan ARDL dapat diperoleh estimasi jangka panjang dan estimasi jangka pendek secara serentak, yang akan menghindarkan terjadinya masalah autokorelasi. Selain itu, metode ARDL juga mampu membedakan antara variabel bebas dan variabel terikat.

\section{METODE PENELITIAN}

Jenis data dalam penelitian ini adalah data sekunder yangn bersifat kuantitatif dalam bentuk data time series. Data tersebut adalah data bulanan suku bunga, nilai tukar atau kurs dan Indeks Harga Saham Gabungan (IHSG) pasar modal Indonesia, untuk periode tahun 2005 sampai dengan 2017. Adapun sumber data diperoleh dari situs resmi Bank Indonesia dan Bursa Efek Indonesia.

Suku bunga (SB) adalah tingkat suku bunga acuan atau BI rate yang dikeluarkan oleh Bank Indonesia, untuk periode bulanan dalam rentang waktu periode Juli 2005 sampai dengan Desember 2017. Data BI rate tersebut dapat diperoleh dari situs resmi Bank Indonesia (www.bi.go.id). Adapun nilai tukar atau kurs adalah perbandingan nilai mata uang Rupiah Indonesia terhadap mata uang asing yang dalam hal ini adalah dengan Dolar Amerika (USD). Data kurs menggunakan rata-rata bulanan kurs spot selama periode penelitian yaitu dari periode Juli 2005 - Desember 2017, yang dapat diperoleh dari situs resmi Bank Indonesia (www.bi.go.id). Selanjutnya data harga saham akan diproksikan dengan data Indeks Harga Saham Gabungan (IHSG) yang merupakan indeks yang mencakup jumlah nilai pasar dari seluruh total saham yang tercatat di Bursa Efek Indonesia pada suatu periode waktu tertentu. Data IHSG yang digunakan adalah IHSG bulanan dari periode Juli 2005 - Desember 2017 yang diperoleh dari situs resmi Bursa Efek Indonesia (BEI) yaitu www.idx.co.id. 
Untuk menjelaskan hubungan antara harga saham, nilai tukar mata uang dan tingkat suku bunga, penelitian ini menggunakan spesifikasi model Autoregressive Distributed Lag (ARDL). Adapun model umum dari ARDL adalah sbb:

$$
\Delta \mathrm{Y}_{\mathrm{t}}=\beta_{0}+\sum_{\mathrm{i}=1}^{\mathrm{n}} \beta_{\mathrm{i}} \Delta \mathrm{y}_{\mathrm{t}-1}+\sum_{\mathrm{i}=0}^{\mathrm{n}} \delta_{i} \Delta \mathrm{x}_{\mathrm{t}-1}+\varphi_{1} \mathrm{y}_{\mathrm{t}-1}+\varphi_{2} \mathrm{x}_{\mathrm{t}-1}+\mu_{\mathrm{t}}
$$

Dimana:

$\beta_{i}, \delta_{t} \quad$ : Koefisien jangka pendek

$\varphi_{1}, \varphi_{2}$ : Koefisien ARDL jangka panjang

$\mu_{t} \quad$ : Disturbance error (white noise)

Sebagaimana telah disebutkan bahwa keunggulan ARDL adalah kemampuannya untuk mendeteksi dinamika jangka panjang maupun jangka pendek. Dalam model umum ARDL pada persamaan (1) merupakan persamaan untuk hubungan jangka pendek.

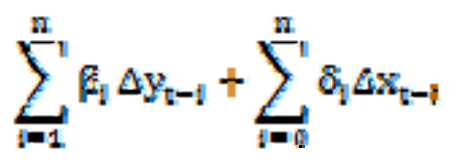

Adapun untuk hubungan jangka panjang ditunjukkan oleh $\varphi_{1} \mathrm{y}_{\mathrm{t}-1}+\varphi_{2} \mathrm{x}_{\mathrm{t}-1}$

Metode estimasi yang akan digunakan adalah menggunakan pendekatan Autoregressive Distributed Lag (ARDL). Model ARDL dipilih oleh karena dengan menggunakan ARDL akan mampu melihat pengaruh Y dan X dari waktu ke waktu, berikut juga pengaruh variabel Y masa lampau terhadap Y masa kini.

Langkah - langkah analisis data dengan menggunakan pendekatan ARDL dalam penelitian adalah sebagai berikut :

1. Melakukan pengujian stasioneritas data. Uji stasioneritas data dilakukan untuk melihat bilamana data terintegrasi pada ordo yang sama atau tidak. Jika data terintegrasi pada ordo yang sama maka penelitian dapat dilakukan dengan metode kointegrasi seperti metode Engel-Granger atau metode Johansen atau metode Johansen dan Juselius. Namun jika hasil pengujian terintegrasi pada ordo yang berbeda, maka akan dilakukan dengan metode ARDL.

2. Melakukan pemilihan model ARDL yang akan digunakan sebagai dasar estimasi koefisien jangka panjang dan jangka pendek. Model ARDL yang dipilih berdasarkan Schawarz Bayesian Criterion (SBC) yang mampu memilih panjang lag terkecil atau berdasarkan Akaike Information Criterion (AIC) untuk memilih panjang lag maksimal yang relevan.

3. Melakukan pengujian kesesuaian model ARDL yang dipilih.

4. Melakukan ARDL bound test. Uji ini dilakukan untuk mengetahui keberadaan hubungan jangka panjang (kointegrasi) dan kausalitas diantara variabel yang dipergunakan dalam model. ARDL bound test dilakukan dengan cara mengestimasi persamaan umum ARDL yang secara bergantian menempatkan setiap variabel yang dipergunakan dalam model sebagai varibel terikat. Pengujian ini dilakukan untuk mengetahui arah kausalitas variabel dalam model.

5. Melakukan estimasi jangka panjang dan dinamika jangka pendek dari model ARDL yang dipilih. 
Bara Zaretta dan Lenni Yovita : Harga Saham, Nilai Tukar Mata Uang Dan Tingkat Suku Bunga Acuan Dalam Model Autoregressive Distributed Lag (ARDL)

\section{HASIL DAN PEMBAHASAN \\ Deskripsi Data}

Penelitian ini menggunakan data bulanan dari Indeks Harga Saham Gabungan (IHSG), kurs tengah Rupiah terhadap Dolar Amerika (KURS) dan suku bunga acuan Bank Indonesia atau BI Rate (BIRT). Periode data yang sekaligus periode penelitian adalah Juli 2005 Desember 2017, sehingga total jumlah observasi adalah 150 observasi. Ketiga variabel data dalam penelitian ini akan ditransformasikan ke dalam logaritma natural, agar ketiga variabel tersebut dapat digunakan dalam model linier dan berdistribusi normal.

Tabel 1. Deskripsi Statistik Data

\begin{tabular}{|l|c|c|c|}
\hline & LN_IHSG & LN_KURS & LN_BIRT \\
\hline Nilai Rata-rata & 8.078915 & 9.259111 & 1.968922 \\
Nilai Maksimum & 8.795678 & 9.574713 & 2.545531 \\
Nilai Minimum & 6.956631 & 9.051579 & 1.446919 \\
\hline
\end{tabular}

Sumber : Data diolah

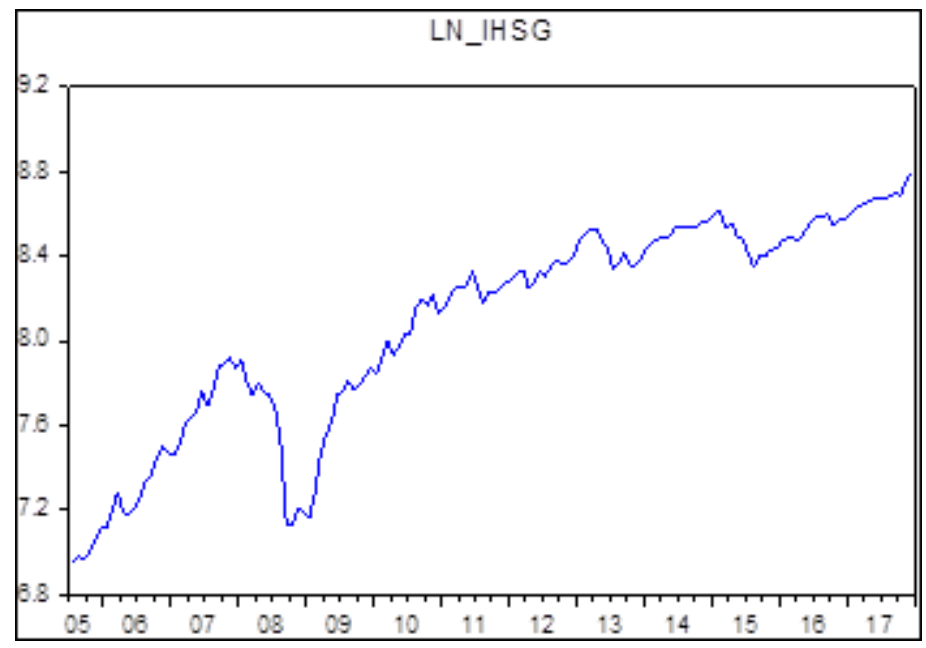

Gambar 1. Line Plot Log Data IHSG

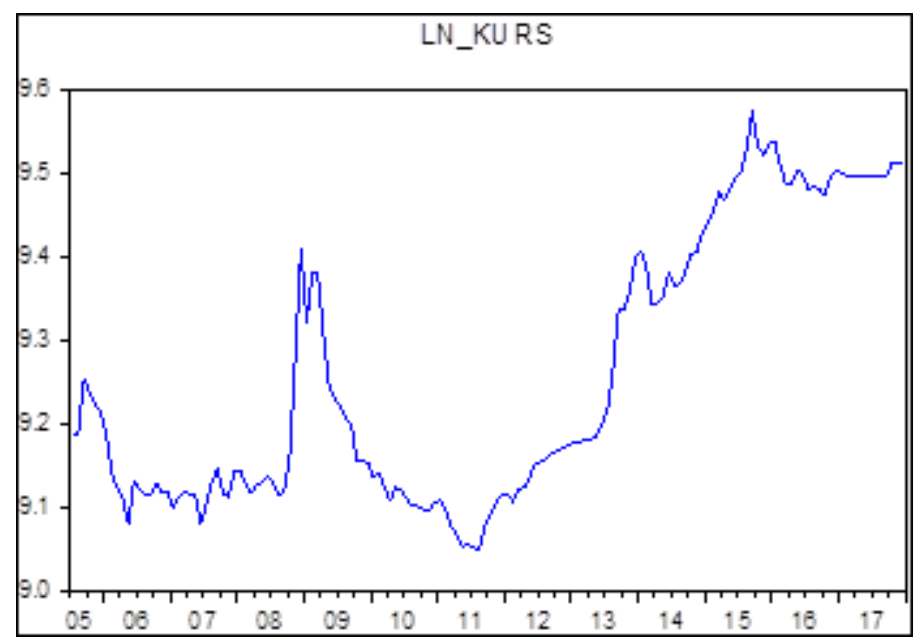

Gambar 2. Line Plot Log Data KURS 


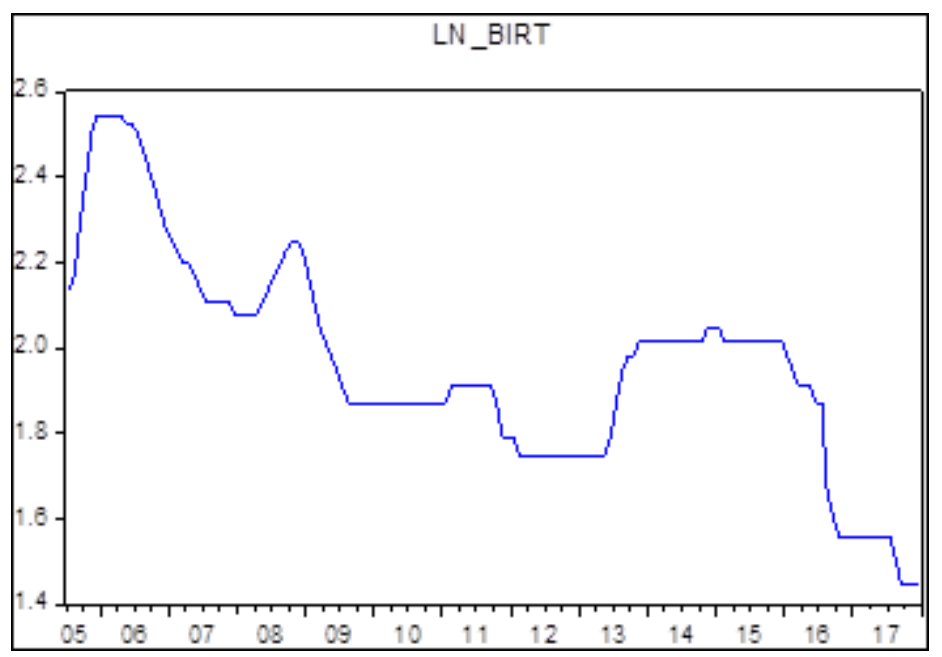

Gambar 3. Line Plot Log Data BI Rate

Gambar 1, 2 dan 3 merupakan grafik dari data - data variabel yang digunakan dalam penelitian ini. Secara visual terlihat bahwa data ketiga variabel tersebut bervariasi dan berflutuasi. Dari grafik line plot tersebut juga terlihat fenomena yang cukup unik dari pergerakan ketiga variabel. Data IHSG dari periode 2005 - 2017 mempunyai tren naik, namun pernah terjadi cerukan yang cukup dalam di tahun 2008. Demikian juga dengan data Kurs memiliki tren naik dengan cerukan dalam di periode 2011. Berkebalikan dengan dua variabel sebelumnya, data BI Rate justru mempunyai tren turun dengan nilai terendah terjadi dalam periode 2017. Secara visual terdapat fenomena menarik yang terlihat, misal pada periode akhir 2008 pada saat terjadinya krisis terlihat nilai IHSG turun tajam dan pada periode tersebut juga terjadi pelemahan Rupiah terhadap Dolar AS yang cukup tinggi. Kondisi krisis tersebut direspon pemerintah dengan menaikkan tingkat suku bunga acuan atau $\mathrm{BI}$ rate untuk menahan pelemahan Rupiah.

Pada periode tahun 2009 - 2011 terlihat bahwa Rupiah bergerak menguat terhadap Dolar Amerika, sehingga pada rentang periode yang sama BI rate bergerak turun kemudian stabil. Respon senada ditunjukkan oleh IHSG yang pada periode tersebut juga bergerak naik. Namun fenomena yang cukup menarik terjadi periode selanjutnya yaitu 2011 - 2017 dimana nilai Rupiah kembali mengalami depresiasi yang cukup tinggi, BI rate baru mengalami kenaikan pada tahun 2013 hingga cukup stabil sampai 2015 dan selanjutnya sampai 2017 justru bergerak turun. Adapun IHSG pada periode tersebut cenderung stabil bergerak naik. Dengan demikian, pelemahan kurs tidak selalu direspon dengan menaikkan suku bunga acuan, dan tidak selalu direspon negatif oleh pasar modal.

\section{Unit Root Test}

Uji akar unit atau Unit Root Test adalah pengujian data untuk mengetahui bilamana data yang digunakan dalam suatu penelitian stasioner atau tidak. Sekumpulan data dinyatakan stasioner bilamana nilai rata - rata dan varian dari data time series tersebut tidak mengalami perubahan secara sistematik sepanjang waktu atau konstan (Nachrowi dan Haridus Usman, 2006). Uji yang sering digunakan dalam unit root test ini adalah uji Augmented Dickey Fuller (ADF) atau uji Phillips - Peron. Keduanya mengindikasikan keberadaan akar unit sebagai hipotesis null. Hasil pengujian unit root dengan Eviews 9.5 sebagaimana pada tabel 2. 
Bara Zaretta dan Lenni Yovita : Harga Saham, Nilai Tukar Mata Uang Dan Tingkat Suku Bunga Acuan Dalam Model Autoregressive Distributed Lag (ARDL)

Uji Unit Akar pada Tingkat Level

\begin{tabular}{|c|c|c|c|c|}
\hline \multicolumn{3}{|l|}{ Method } & Statistic & Prob. \\
\hline \multicolumn{3}{|c|}{ ADF - Fisher-Chi Square } & 4.15689 & 0.6555 \\
\hline \multicolumn{3}{|c|}{ ADF - Choi Z-stat } & 0.24931 & 0.5984 \\
\hline Series & Prob. & Lag & Max Lag & Obs \\
\hline $\mathrm{D}\left(\mathrm{LN} \_\mathrm{BIRT}\right)$ & 0.3495 & 2 & 13 & 147 \\
\hline$D($ LN_IHSG) & 0.4244 & 1 & 13 & 148 \\
\hline $\mathrm{D}$ (LN_KURS) & 0.8435 & 1 & 13 & 148 \\
\hline
\end{tabular}

Uji Unit Akar pada Tingkat First Difference

\begin{tabular}{|c|c|c|c|c|}
\hline \multicolumn{3}{|l|}{ Method } & Statistic & Prob. \\
\hline \multicolumn{3}{|c|}{ ADF - Fisher-Chi Square } & 151.155 & 0.0000 \\
\hline \multicolumn{3}{|c|}{ ADF - Choi Z-stat } & -11.2665 & 0.0000 \\
\hline Series & Prob. & Lag & Max Lag & Obs \\
\hline D(LN_BIRT) & 0.0000 & 1 & 13 & 147 \\
\hline D(LN_IHSG) & 0.0000 & 0 & 13 & 148 \\
\hline D(LN_KURS) & 0.0000 & 0 & 13 & 148 \\
\hline
\end{tabular}

Berdasarkan hasil uji unit root dengan ADF, ketiga varibel dalam penelitian ini tidak ada yang stasioner pada tingkat level. Ditunjukkan dengan probabilitas lebih besar dari 5\%. Namun ketika dilakukan unit root test pada level first difference, dari signifikansi probabilitas, ketiga variabel stasioner.

\section{Autoregressive Distributed Lag Model}

Setelah melakukan uji stasioneritas yang diperoleh hasil bahwa ketiga variabel ternyata stasioner pada orde yang sama I (1) (first difference level) dan tidak pada I (2), sudah sesuai untuk persyaratan dilakukannya pendekatan Autoregressive Distributed Lag (ARDL).

Tabel 3. Model ARDL

\begin{tabular}{|c|c|c|c|c|}
\hline \multicolumn{5}{|c|}{$\begin{array}{l}\text { Dependent Variable: } \mathrm{D}\left(\mathrm{LN} \_\mathrm{IHSG}\right) \\
\text { Method: ARDL } \\
\text { Model selection method: Akaike info } \\
\text { Dynamic regressors (12 lags, automat } \\
\text { Number of models evalulated: } 2028 \\
\text { Selected Model: ARDL }(4,9,3)\end{array}$} \\
\hline Variable & Coefficient & $\begin{array}{l}\text { Std. } \\
\text { Error }\end{array}$ & t-Statistic & Prob.* \\
\hline$D\left(L N \_I H S G(-1)\right)$ & 0,342011 & 0,088838 & 3,849821 & 0,0002 \\
\hline$D($ LN_IHSG(-2)) & $-0,126298$ & 0,100736 & $-1,253751$ & 0,2123 \\
\hline D(LN_IHSG(-3)) & 0,295584 & 0,102411 & 2,88624 & 0,0046 \\
\hline$D($ LN_IHSG(-4)) & $-0,114408$ & 0,102586 & $-1,115238$ & 0,2670 \\
\hline D(LN_KURS) & 0,398814 & 0,233096 & 1,710944 & 0,0897 \\
\hline$D\left(L N \_K U R S(-1)\right)$ & 0,212576 & 0,233325 & 0,911077 & 0,3641 \\
\hline $\mathrm{D}\left(\mathrm{LN} \_K U R S(-2)\right)$ & $-0,077690$ & 0,225063 & $-0,34519$ & 0,7306 \\
\hline $\mathrm{D}\left(\mathrm{LN} \_K U R S(-3)\right)$ & $-0,001667$ & 0,194527 & $-0,008568$ & 0,9932 \\
\hline D(LN_KURS(-4)) & 0,407050 & 0,188312 & 2,161565 & 0,0326 \\
\hline$D\left(L N \_K U R S(-5)\right)$ & $-0,237388$ & 0,190667 & $-1,245041$ & 0,2155 \\
\hline D(LN_KURS(-6)) & 0,516479 & 0,192110 & 2,688449 & 0,0082 \\
\hline D(LN_KURS(-7)) & $-0,547935$ & 0,193558 & $-2,830862$ & 0,0054 \\
\hline D(LN_KURS(-8)) & 0,352425 & 0,195229 & 1,805187 & 0,0735 \\
\hline D(LN_KURS(-9)) & $-0,338798$ & 0,189141 & $-1,791242$ & 0,0758 \\
\hline$D\left(L N \_B I R T\right)$ & $-0,213158$ & 0,190912 & $-1,116528$ & 0,2664 \\
\hline $\mathrm{D}\left(\mathrm{LN} \_B \mid R T(-1)\right)$ & $-0,066355$ & 0,200920 & $-0,330257$ & 0,7418 \\
\hline $\mathrm{D}\left(\mathrm{LN} \_\mathrm{BIRT}(-2)\right)$ & 0,160851 & 0,201705 & 0,797458 & 0,4267 \\
\hline $\mathrm{D}\left(\mathrm{LN} \_B I R T(-3)\right)$ & $-0,532091$ & 0,189507 & $-2,807766$ & 0,0058 \\
\hline
\end{tabular}




\begin{tabular}{|c|c|c|c|c|}
\hline C & 0,000141 & 0,005663 & 0,024938 & 0,9801 \\
\hline & \multicolumn{4}{|c|}{ Mean dependent } \\
\hline R-squared & 0,303842 & var & & 0,011448 \\
\hline Adjusted R-squared & 0,200281 & S.D. dep & ndent var & 0,060489 \\
\hline S.E. of regression & 0,054093 & Akaike i & fo criterion & 2,870638 \\
\hline Sum squared resid & 0,354056 & $\begin{array}{l}\text { Schwarz } \\
\text { Hannan }\end{array}$ & $\begin{array}{l}\text { criterion } \\
\text { Quinn }\end{array}$ & 2,471415 \\
\hline Log likelihood & 219,9446 & criter. & & 2,708406 \\
\hline F-statistic & 2,933944 & Durbin- & Jatson stat & 1,979411 \\
\hline Prob(F-statistic) & 0,000243 & & & \\
\hline
\end{tabular}

Hasil seleksi model menggunakan nilai AIC menyatakan bahwa model ARDL(4,9,3) adalah model terbaik dengan nilai Akaike Criterion terkecil -2,87. Dengan demikian bentuk umum model ARDL $(4,9,3)$ yang akan diestimasi adalah, sbb:

$$
\begin{aligned}
& d\left(\ln \_i h s g\right)=\beta_{1} d\left(\ln \_i h s g\right)_{t-1}-\beta_{2} d\left(\ln \_i h s g\right)_{t-2}+\beta_{3} d\left(\ln \_i h s g\right)_{t-3}-\beta_{4} d\left(\ln \_i h s g\right)_{t-4}+\beta_{5} d\left(\ln \_k u r s\right)_{t} \\
& +\beta_{6} d\left(\ln \_k u r s\right)_{t-1}-\beta_{7} d\left(\ln _{-} k u r s\right)_{t-2}-\beta_{8} d\left(\ln _{-} k u r s\right)_{t-3}+\beta_{9} d\left(\ln _{-} k u r s\right)_{t-4}-\beta_{10} d\left(\ln _{-} k u r s\right)_{t-5} \\
& +\beta_{11} d\left(\ln _{-} k u r s\right)_{t-6}-\beta_{12} d\left(\ln \_k u r s\right)_{t-7}+\beta_{13} \mathrm{~d}\left(\ln \_k u r s_{t-8}-\beta_{14} \mathrm{~d}\left(\ln _{-} k u r s\right)_{t-9}-\beta_{15} d\left(\ln \_b i r t\right)_{t}\right. \\
& -\beta_{16} \mathrm{~d}\left(\ln \_ \text {birt }\right)_{t-1}+\beta_{17} \mathrm{~d}\left(\ln \_ \text {birt }\right)_{t-2}-\beta_{18} \mathrm{~d}\left(\ln _{-} \text {birt }\right)_{t-3}+e_{t}
\end{aligned}
$$

Dimana :

$\beta i \quad$ : koefisien parameter model yang diestimasi

$e_{t} \quad:$ residual model

i $\quad: 1,2,3, \ldots, 18$

\section{Pengujian Kesesuaian Model ARDL(4,9,3)}

Pengujian kesesuaian model ARDL yang terpilih perlu dilakukan agar model penelitian yang dibentuk tidak melanggar kaidah - kaidah ekonometrika. Pengujian diagnosa model ARDL $(4,9,3)$ terutama akan dilakukan dengan pemeriksaan Autokorelasi dan stabilitas model.

Uji Autokorelasi pada model ARDL $(4,9,3)$ akan menggunakan uji Breusch-Godfrey Lagrange Multiplier (BGLM), dengan hipotesis yang digunakan adalah sbb:

$\mathrm{H} 0$ : tidak terdapat autokorelasi pada residual model $\operatorname{ARDL}(4,9,3)$

H1 : terdapat autokorelasi pada residual model ARDL $(4,9,3)$

Tabel 4. Hasil Uji Autokorelasi

Breusch-Godfrey Serial Correlation LM Test:

\begin{tabular}{llll}
\hline \hline F-statistic & 1.041586 & Prob. F(9,112) & 0.4119 \\
Obs*R-squared & 10.81282 & Prob. Chi-Square(9) & 0.2888 \\
\hline
\end{tabular}

Berdasarkan hasil pengolahan data sebagaimana pada tabel 4 diketahui bahwa $p-$ value statistik untuk uji BGLM tersebut adalah 0,2888. Hasil tersebut mengindikasikan bahwa pada tingkat kepercayaan 95\% null hypothesis tidak dapat ditolak, yang artinya tidak terdapat autokorelasi pada residual model ARDL(4,9,3). 
Uji stabilitas model ARDL $(4,9,3)$ dalam penelitian ini menggunakan uji CUSUM dengan tingkat kepercayaan 95\%. Hasil uji CUSUM untuk model ARDL(4,9,3) dalam penelitian ini sebagaimana dalam gambar 4. Stabililitas model ditentukan dari posisi CUSUM line yang berwarna biru berada diantara dua significance line 5\% yang berwarna merah. Untuk model ARDL $(4,9,3)$ CUSUM line berada diantara significance line yang membuktikan bahwa model ARDL $(4,9,3)$ stabil.

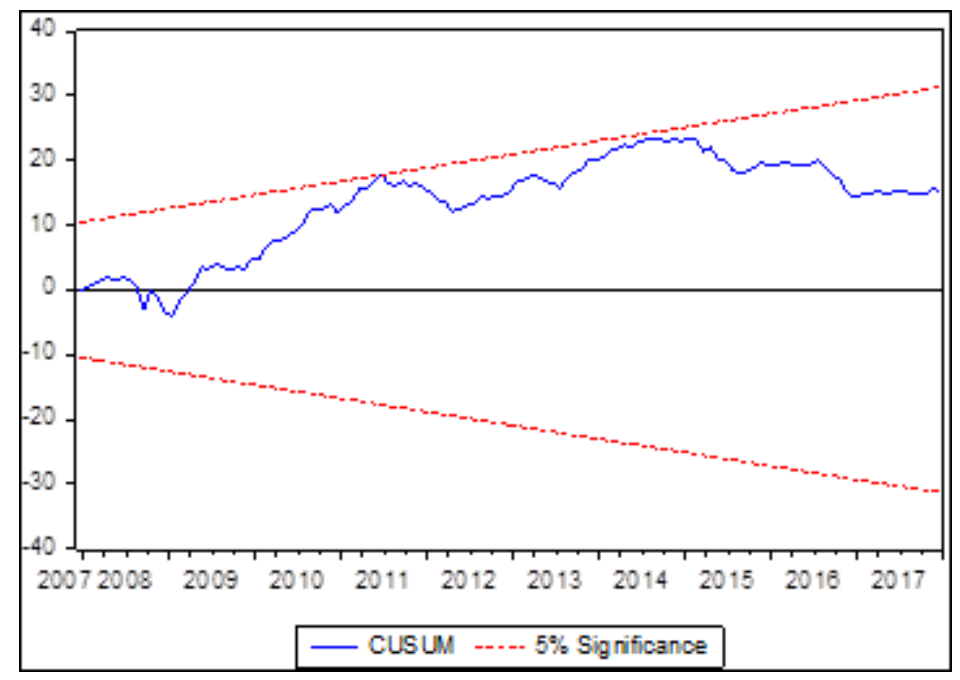

Gambar 4. Uji Stabilitas Model - Uji CUSUM

\section{Bounds Test}

Uji Bounds dilakukan untuk menguji adanya long-run association dalam model ARDL yang terpilih. Hasil dari Bounds test ini akan lebih menitikberatkan pada nilai Fstatistic. Nilai F-statistic akan dibandingkan dengan Pesaran critical value pada level 5\%, yang juga telah disediakan oleh Eviews 9.5. Apabila F-statistic mempunyai nilai yang melebihi upper Bounds value maka null hypothesis yang menyatakan bahwa tidak terjadi long-run association ditolak, yang artinya variabel - variabel dalam penelitian bergerak bersama - sama dalam jangka panjang.

Tabel 5. Bounds Test Model ARDL(4,9,3)

\begin{tabular}{|ccc|}
\hline \multicolumn{3}{|c}{ Null Hypothesis: No long-run relationships exist } \\
\hline \hline Test Statistic & Value & k \\
\hline \hline F-statistic & 4.934387 & 2 \\
\hline \hline \multicolumn{3}{|c}{ Critical Value Bounds } \\
\hline \hline Significance & I0 Bound & I1 Bound \\
\hline \hline $10 \%$ & 2.63 & 3.35 \\
$5 \%$ & 3.1 & 3.87 \\
$2.5 \%$ & 3.55 & 4.38 \\
$1 \%$ & 4.13 & 5 \\
\hline \hline
\end{tabular}

Berdasarkan hasil Bounds Test untuk model ARDL $(4,9,3)$ pada tabel 5, terlihat bahwa nilai F-statistic model adalah 4,934387 lebih besar dari nilai upper bound pada level $5 \%$, bahkan masih juga lebih besar dibandingkan dengan upper bound pad level 2,5\%. Hal ini 
membuktikan bahwa ketiga variabel dalam penelitian ini yaitu IHSG, Kurs dan BI Rate terjadi kointegrasi dalam jangka panjang atau bisa dikatakan bahwa ketiga variabel tersebut bergerak bersama - sama dalam jangka panjang.

\section{Dynamic Cointgration dan Speed of Adjustment}

Sampai dengan dilakukannya bound test diketahui bahwa ketiga variabel dalam penelitian ini mempunyai kointegrasi jangka panjang. Pada model ARDL $(4,9,3)$ diperoleh hasil long run coefficients sebagaimana dalam tabel 6. Dari hasil estimasi jangka panjang terlihat bahwa variabel BI Rate yang memiliki pengaruh negatif dan signifikan terhadap IHSG. Berbeda dengan BI Rate variabel nilai tukar Rupiah terhadap Dolar Amerika berpengaruh positif, namun tidak signifikan terhadap IHSG. Hal ini menjawab fenomena yang terjadi pada periode tahun 2011 - 2017 dimana nilai Rupiah mengalami depresiasi yang cukup tinggi namun IHSG tetap bergerak naik, hanya terkoreksi sedikit namun kembali bergerak naik. Respon IHSG tersebut berbeda dengan periode sebelumnya yaitu pada akhir 2008 dimana terjadi pelemahan yang cukup tajam oleh Rupiah yang direspon dengan jatuhnya nilai IHSG. Dengan demikian, depresiasi Rupiah terhadap Dolar Amerika tidak selalu direspon sama oleh IHSG.

Tabel 6. Estimasi Jangka Pendek dan Koefisien Jangka Panjang Cointegrating Form

\begin{tabular}{lrrrr}
\hline \hline \multicolumn{1}{c}{ Variable } & Coefficient & Std. Error & \multicolumn{1}{c}{ t-Statistic } & \multicolumn{1}{l}{ Prob. } \\
\hline \hline D(LN_IHSG(-1), 2) & -0.054878 & 0.127869 & -0.429171 & 0.6686 \\
D(LN_IHSG(-2), 2) & -0.181176 & 0.112516 & -1.610218 & 0.1100 \\
D(LN_IHSG(-3), 2) & 0.114408 & 0.092173 & 1.241230 & 0.2169 \\
D(LN_KURS, 2) & 0.398814 & 0.200955 & 1.984595 & 0.0495 \\
D(LN_KURS(-1), 2) & -0.072477 & 0.299280 & -0.242172 & 0.8091 \\
D(LN_KURS(-2), 2) & -0.150167 & 0.302617 & -0.496227 & 0.6206 \\
D(LN_KURS(-3), 2) & -0.151834 & 0.293252 & -0.517757 & 0.6056 \\
D(LN_KURS(-4), 2) & 0.255216 & 0.282531 & 0.903319 & 0.3682 \\
D(LN_KURS(-5), 2) & 0.017828 & 0.272583 & 0.065404 & 0.9480 \\
D(LN_KURS(-6), 2) & 0.534307 & 0.255759 & 2.089103 & 0.0388 \\
D(LN_KURS(-7), 2) & -0.013628 & 0.217963 & -0.062522 & 0.9503 \\
D(LN_KURS(-8), 2) & 0.338798 & 0.180573 & 1.876241 & 0.0630 \\
D(LN_BIRT, 2) & -0.213158 & 0.177907 & -1.198142 & 0.2332 \\
D(LN_BIRT(-1), 2) & 0.371240 & 0.208232 & 1.782817 & 0.0771 \\
D(LN_BIRT(-2), 2) & 0.532091 & 0.175371 & 3.034088 & 0.0030 \\
CointEq(-1) & -0.603111 & 0.134101 & -4.497434 & 0.0000 \\
\hline \hline Cointeq = D(LN_IHSG) - (1.1339*D(LN_KURS) -1.0790*D(LN_BIRT) + & & & \\
0.0002) & & & & \\
\hline \hline
\end{tabular}

\begin{tabular}{lrrrr}
\multicolumn{5}{c}{ Long Run Coefficients } \\
\hline \hline \multicolumn{1}{c}{ Variable } & Coefficient & Std. Error & \multicolumn{1}{c}{ t-Statistic } & Prob. \\
\hline \hline D(LN_KURS) & 1.133900 & 1.175032 & 0.964995 & 0.3365 \\
D(LN_BIRT) & -1.078994 & 0.437266 & -2.467589 & 0.0150 \\
C & 0.000234 & 0.009363 & 0.025012 & 0.9801 \\
\hline
\end{tabular}

Melalui pendekatan ARDL kita juga dapat memperoleh estimasi jangka pendek yang dapat dilihat melalui nilai ECT atau CointEq. Melalui hasil uji kointegrasi pada tabel 6 diketahui bahwa nilai CointEq(-1) $=-0,6031$ dan signifikan pada level 5\%, yang berarti terjadi kointegrasi jangka pendek dalam model ini. Koefisien CointEq selanjutnya akan digunakan untuk mengukur speed of adjustment yang merupakan kecepatan penyesuaian dalam merespon terjadinya perubahan. Nilai ECT atau CointEq valid jika koefisien bernilai negatif dengan probabilitas signifikan pada level 5\%. Pada penelitian ini, model ARDL $(4,9,3)$ telah 
Bara Zaretta dan Lenni Yovita : Harga Saham, Nilai Tukar Mata Uang Dan Tingkat Suku Bunga Acuan Dalam Model Autoregressive Distributed Lag (ARDL)

memenuhi persyaratan validitas tersebut, sehingga dalam penelitian ini kita dapat menyimpulkan bahwa model akan menuju pada keseimbangan dengan kecepatan $60,31 \%$ per bulan.

\section{SIMPULAN}

Penelitian ini bertujuan untuk melihat dinamika hubungan antara nilai tukar Rupiah terhadap Dolar Amerika, tingkat suku bunga acuan atau BI Rate dan harga saham yang diproksikan dengan Indeks Harga Saham Gabungan (IHSG), menggunakan pendekatan Autoregressive Distributed Lag (ARDL). Penelitian terutama fokus pada periode tahun 2005 sampai dengan 2017 dimana dalam periode - periode tersebut terjadi beberapa kali pelemahan nilai tukar Rupiah terhadap Dolar Amerika oleh karena terjadi krisis global. Dalam beberapa kesempatan Pemerintah Indonesia menggunakan mekanisme menaikkan tingkat suku bunga acuan atau BI Rate untuk menahan depresiasi Rupiah, dan beberapa waktu memang cukup berhasil. Pelemahan atau penguatan nilai tukar dan mekanisme perubahan tingkat suku bunga acuan juga dipercaya akan memberikan dampak terhadap pasar modal yang dalam hal ini akan dicerminkan melalui nilai indeks saham gabungan yang listed di dalamnya.

Melalui pendekatan model ARDL, dalam penelitian ini diketahui bahwa pada periode tahun 2005 - 2017 pergerakan nilai tukar dan perubahan tingkat suku bunga acuan berpengaruh terhadap pasar modal. Nilai tukar Rupiah terhadap Dolar Amerika, BI Rate dan IHSG terbukti memiliki kointegrasi jangka panjang atau bergerak bersama - sama dalam jangka panjang. Walaupun jika kita melakukan estimasi secara parsial, terbukti bahwa IHSG tidak selalu mempunyai respon yang sama terhadap pelemahan Rupiah terhadap Dolar Amerika. Namun tidak hanya jangka panjang, ketiga variabel tersebut juga mempunyai dinamika hubungan jangka pendek yang mempunyai kecepatan penyesuaian menuju keseimbangan yang cukup tinggi sampai $60 \%$ tiap bulannya. Seluruh kondisi ini menunjukkan bahwa variabel macroeconomics dan kebijakan moneter yang diambil harus selalu memperhatikan dampaknya terhadap sektor keuangan terutama pasar modal, karena ketiganya saling berhubungan dan mempengaruhi.

\section{DAFTAR PUSTAKA}

Ajaz, T., Nain, MZ., Kamaiah, B dan Sharma, NK. 2016. Stock Prices, Exchange Rate and Interest Rate: Evidence Beyond Symmetry. Journal of Financial Economic Policy. 9(1)

Arifin, Ali. 2004. Membaca Saham. Yogyakarta: UPP AMP YKPN

Bahmani-Oskooee, M. dan Sohrabian, A. 1992. On The Relation Between Stock Prices And Exchange Rates: A Review Article. Journal of Economic Studies.42 (4): 707-732.

Bernanke, B. dan Kuttner, K.N. 2005. What Explains The Stock Market's Reaction To Federal Reserve Policy?. The Journal of Finance. 60 (3): 1221-1257.

Cassola, N. dan Morana, C. 2004. Monetary Policy And The Stock Market In The Euro Area. Journal of Policy Modelling. 26 (3): 387-399.

Chulia, H., Martens, M. dan Dijk, D. 2010. Asymmetric Effects Of Federal Funds Target Rate Changes On S\&P100 Stock Returns, Volatilities And Correlations. Journal of Banking and Finance. 34 (4): 834-839.

Fama, E.1970. Efficient Capital Markets: A Review Of Theory And Empirical Work. Journal of Finance. 25 (2): 383-417.

Farka, M. 2009. The Effect Of Monetary Policy Shocks On Stock Prices Accounting For Endogeneity And Omitted Variable Biases. Review of Financial Economics. 18 (1): 47-55.

Gujarati, D.N. 2003. Basic Econometric. New York : The Mc.Graw-Hill Companies Inc. 
Ho, S.Y. dan Iyke, B.N. 2016. Determinant Of Stock Market Development: A Review Of The Literature. Studies in Economics and Finance. 34 (1): 143-164.

Ismail, M.T. dan Isa, Z.B. 2009. Modeling The Interactions Of Stock Price And Exchange Rate In Malaysia. The Singapore Economic Review. 54 (4): 605-619.

Maryanti, Sri. 2009. Analisis Pengaruh Tingkat Suku Bunga SBI dan Nilai Kurs Dolar AS terhadap Indeks Harga Saham Gabungan (IHSG) (Studi pada Bursa Efek Jakarta). Pekbis Jurnal.1

Novita, M. dan Nachrowi, N.D. 2005. Dynamic Analysis Of The Stock Price Index And The Exchange Rate Using Vector Auto Regression (VAR) : An Empirical Study In Jakarta Stock Exchange 2001 - 2004. Journal of Economics and Finance in Indonesia. 53 (3): 263-278.

Pesaran, M.H., Shin, Y. dan Smith, R.J. 2001. Bounds Testing Approaches To The Analysis Of Level Relationships. Journal of Applied Econometrics. 16 (3): 289-326.

Phylaktis, K. dan Ravazzolo, F. 2005. Stock Prices And Exchange Rate Dynamics. Journal of International Money and Finance. 24 (7): 1031-1053.

Ross, S.A. 1976. The Arbitrage Theory Of Capital Asset Pricing. Journal of Economic Theory. 13: 341-360.

Shin, Y., Yu, B.C. dan Greenwood-Nimmo, M. 2014. Modelling asymmetric cointegration and dynamic multipliers in a nonlinear ARDL framework. Econometric Methods and Applications. Springer.

Sunariyah. 2006. Pengantar Pengetahuan Pasar Modal. Edisi ke-5. Yogyakarta: BPFE.

Utami, Mudji dan Rahayu, Mudjilah. 2003. Peranan Profitabilitas, Suku Bunga, Inflasi dan Nilai Tukar dalam Mempengaruhi Pasar Modal Indonesia Selama Krisis Ekonomi. Jurnal Manajemen dan Kewirausahaan. 5 (2).

Wiyani, Wahyu dan Wijayanto, Andi. 2005. Pengaruh Nilai Tukar Rupiah, Tingkat Suku Bunga Deposito dan Volume Perdagangan Saham terhadap Harga Saham. Jurnal Keuangan dan Perbankan. IX (3).

Yang, Z., Tu, A.H. dan Zeng, Y. 2014. Dynamic Linkages Between Asian Stock Prices And Exchange Rates: New Evidence From Causality In Quantiles. Applied Economics. 46 (11): 1184-1201.

Zare, R. dan Azali, M. 2015. The Association Between Aggregated And Disaggregated Stock Prices With Monetary Policy Using Asymmetric Cointegration And Error-Correction Modeling Approaches. Review of Development Finance. 5 (1): 64-69.

www.bi.go.id

www.idx.co.id 